\title{
A KANCA KOLOSZTRUMÁNAK ÉS TEJÉNEK ÖSSZETÉTELE - IRODALMI ÖSSZEFOGLALÓ
}

\author{
- hlo \\ COMPOSITION OF MARE'S COLOSTRUM AND MILK - A REVIEW

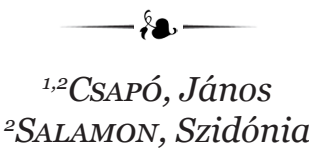 \\ in \\ ${ }^{1}$ Debreceni Egyetem, Mezőgazdaság-, Élelmiszer-tudományi és Környezetgazdálkodási Kar, Élelmiszer-technológiai Intézet \\ (Debrecen University, Faculty of Agricultural and Food Sciences and Environmental Management, Institute of Food Technology) \\ H-4032 Debrecen, Böszörményi út 138. \\ e-mail: csapo.janos@gmail.hu \\ ${ }^{2}$ Sapientia Erdélyi Magyar Tudományegyetem Kolozsvár, Műszaki és Társadalomtudományi Kar Csíkszereda, Élelmiszer-tudományi Tanszék, \\ (Sapientia Hungarian University of Transsylvania Cluj Napoca, Faculty of Miercurea Ciuc, Department of Food Science) \\ RO-410o Csíkszereda, Szabadság tér 1. Románia
}

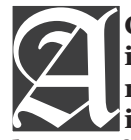

Currently, there is considerable interest in the use of mare's milk for human consumption in Western Europe. It has been suggested that mare's milk may be curative agent for metabolic and allergic diseases and, consequently, the price paid for mare's milk has increased greatly, for this research is needed to evaluate the value of mare's milk as a human food. Based on the fact that data on composition, of mare's milk are limited, a study was initiated to evaluate the composition of mare's milk. The objectives of the experiment were to evaluate time changes in milk composition from foaling to 45 days of lactation as well. The author summarise the result of their experiments, and compare to the data are located in the literature, and give an overview about the composition of the colostrum and milk. They established that the total protein, whey protein, casein and NPN contents, respectively, were 16.41, 13.46, 2.95 and o.052\% for colostrum immediately after parturition; 4.13, 2.11, 2.02 and $0.043 \%$ for milk between the 2 nd and $5^{\text {th }}$ days and $2.31,1.11,1.20$ and $0.031 \%$ for milk in the 8th to $45^{\text {th }}$ days of lactation. The ratios of true protein and whey protein to total protein decreased, while the comparable ratios of casein and NPN increased from foaling to 45 days. The amino acid content of colostrum and milk decreased during the first 45 days of lactation. Most of the essential amino acids (threonine, valine, cystine, tyrosine and lysine) decreased, while glutamic acid and proline increased in the milk protein after parturition. Therefore, the biological value of the milk protein is highest (132.3) immediately after parturition due to very high levels of threonine and lysine. This value decreases in the course of 5 days to 119.7 and to 107.9 on the 45th day of lactation. The total solid and the fat content, respectively, of the colostrum and milk were 24.25 to $26.28 \%$ and 2.85 to $2.93 \%$ on the first day of lactation, 12.15 to $12.78 \%$ and 2.05 to $2.17 \%$ on the 2nd to 5 th days and 10.37 to $10.61 \%$ and 1.04 to $1.32 \%$ on the 8th to 45th days of lactation. The concentrations of octanoic, decanoic, dodecanoic, miristic and palmitoleic acids increased over time while stearic, oleic, linolic and linolenic acids decreased. Mare's milk fat contained octanoic, decanoic, dodecanoic, linolic, linolenic, stearic, miristic and palmitic acids, respectively, in respective ratios of approximately 9.6, 3.1, 2.1, 4.4, 224, $0.2,0.6$ and 0.5 times those of concentrations in cow's milk. The essential fatty acid content of mare's milk was higher than that of cow's milk. Content of vitamins A, D, K and C of colostrum $(0.88,0.0054,0.043$, $23.8 \mathrm{mg} / \mathrm{kg})$ was found to be 1.4 to 2.6 times the levels in normal milk $(0.34,0.0032,0.029,17.2 \mathrm{mg} /$ $\mathrm{kg}$ ). There was no significant difference found between vitamin $\mathrm{E}$ content of colostrum and milk $(1.342$ and $1.128 \mathrm{mg} / \mathrm{kg})$. Ash content of colostrum $(0.592 \%)$ was significantly higher than that of normal milk (0.405\%). Calcium content was lowest immediately after foaling $(747.7 \mathrm{mg} / \mathrm{kg})$ and reached a maximum on day $5(953.7 \mathrm{mg} / \mathrm{kg})$. Zinc and copper content decreased after reaching a maximum on day 5 , while manganese content increased to day 5 and maintained that level. 
The macro- and microelement content (mg/ kg) of colostrum and milk, respectively, was: potassium, 928.6 and 517.2 ; sodium, 320.0 and 166.6; calcium, 747.7 and 822.9; phosphorus, 741.7 and 498.8; magnesium, 139.7 and 65.87; zinc, 2.95 and 1.99; iron, 0.996 and 1.209; copper, 0.606 and 0.249 and manganese, 0.0447 and 0.0544 . The low sodium content of mare's milk is a particularly desirable attribute for a dietary component for cardiovascular disorder and hypertension patients.

\section{A Kolosztrum és a TEJ FEHÉRJETARTALMA ÉS FEHÉRJEFRAKCIÓI - PROTEIN Content and Protein Fractions of Colostrum AND MilK}

A kancatej összes fehérje (nyersfehérje) tartalma (N\%x6,38), a kolosztrum-periódust kivéve, a legtöbb publikáció szerint 1,7-3,0\% között változik. Az összes fehérjén belül a kazein aránya a legtöbb szerző szerint nem éri el az 50\%-ot, ennek megfelelően a savófehérje aránya több mint 50\%. Az NPN (nem fehérje nitrogén) aránya a kancatejben meglepően nagy az összes többi állatfajhoz hasonlítva, és átlagosan eléri - az összes nitrogéntartalmon belül - a 10\%-ot. Az NPN-tartalom 38-51\%-a karbamid. A proteóz-pepton frakció a kancatej összes nitrogénjéből o,16-o,19\%-ot tesz ki. A kancatej kazeintartalmát, annak fehérjefrakcióit keményítő gélelektroforézissel elemezték, majd megállapították a frakciók aminosav-öszszetételét, $\mathrm{N}$ - és C-terminális aminosavait és a kazeinfrakciók viselkedését a különböző enzimek hatására. A kolosztrum-periódust követően a savófehérje 11-21\%-át az immunglobulinok, 2-15\%-át a szérumalbumin, 26-50\%-át az $\alpha$-laktalbumin, 28-60\%-át pedig a $\beta$-laktoglobulin teszi ki. Az igen nagy eltérések részben a fajták közötti különbséggel magyarázhatók (CIESLA et al., 2009; DUISEMBAEV, 1973; DOREAU és BOULOT, 1990; CSAPÓ-KISS et al., 1994; MALACARNE, 2002; EGITO et al., 2002; MARKIEWICZ KESZYCKA et al., 2013).

A brit szigetek lófajtái kolosztrumának fehérjetartalma 4,84-25,00\% között változik, mely érték sokszorosa a normális tejének. A kancakolosztrum fehérjetartalmáról megállapítják, hogy az hirtelen csökken az ellés utáni 12. óráig, majd a továbbiakban csak kismértékben változik. Többen a kancakolosztrum fehérjetartalmát szintén az ellés után mérték a legnagyobbnak, mely érték folyamatosan csökkent a laktáció 2. hetéig (BALBIERZ et al., 1975, CSAPÓ-KISS et al., 1995).

A póni kolosztrumának összesfehérje-tartalma az ellés utáni 3. óráig 10,6-25,0\% között, immunglobulin-G tartalma $31,2-60,0 \mathrm{mg} / \mathrm{cm}^{3}$, immunglobulin- $\mathrm{T}$ tartalma pedig $0,6-30,0$ $\mathrm{mg} / \mathrm{cm}^{3}$ között alakul. Az előzőeket kiegészítve elmondható, hogy a kolosztrum-periódus a kancánál lényegesen rövidebb ideig tart, mint a tehénnél. A kolosztrum összetétele az ellés utáni 12. óráig mutat lényeges eltérést a normális tejétől, és az ellés utáni 24-96 óra között már csak minimális a változás. A többi állatfajhoz hasonlóan a kolosztrum fehérjetartalma nagy, a legtöbb esetben nagyobb, mint $10 \%$. A savófehérje-frakció aránya a kolosztrumban nagyobb, mint a tejben, és az immunglobulinok az összes fehérjének több mint 80\%-át teszik ki az első fejésű kolosztrumban (TYLER, 1972; DYUSEMBIN és DIDUK, 1966; CEBO et al., 2012; PAGAN és HINTZ, 1986).

A tej fehérjetartalma gyorsan csökken a laktáció 2. hetéig, majd a továbbiakban ez a csökkenés folytatódik a laktáció folyamán. Nincs információ arra nézve, hogy vajon a többi állatfajhoz hasonlóan emelkedik-e a tej fehérjetartalma a laktáció során, hisz a leghoszszabb kísérletek is csak a laktáció 150. napjáig tartottak. Úgy tünik, hogy az NPN-tartalom nem változik a laktáció első két hónapja alatt, és a laktáció nincs szignifikáns hatással a tejfehérje-frakciók arányára a kolosztrum utáni tejben. Némi csökkenés figyelhető meg a korral a tej fehérjetartalmában, bár ez a csökkenés alig éri el a o,2\%-ot. Az első két laktációban nagyobb a tej fehérjetartalma, mint az azt követőkben (GIBBS et al., 1982; DAVIES et al., 1983; BALBIERZ et al., 1975, CSAPÓ-KISS et al., 1995).

$\mathrm{Az}$ irodalmi adatok szerint a tej fehérjetartalma csökken a takarmány energiatartalmának növelésével, ami teljesen ellentmond 
azoknak az eredményeknek, melyeket tejelő marhák esetében kaptak. Egyesek nem találtak összefüggést a takarmány nitrogéntartalma és a tej nyersfehérje-tartalma között, mások viszont erőteljes csökkenést figyeltek meg a tej fehérje- és NPN-tartalmában akkor, amikor csökkentették a takarmány nitrogéntartalmát (DAVIES et al., 1983, DOREAU et al., 1990).

A fajta hatását tanulmányozva a tej öszszetételére egyesek nem tudtak érdemleges befolyásról beszámolni, mások szerint viszont a több tejet adó fajták tejének nagyobb a fehérjetartama, bár ismertek olyan adatok is, hogy még az igen nagy testtömeg különbséggel rendelkező fajták esetében sincs a tej fehérjetartalmában különbség. Néhányan úgy találták, hogy a hidegvérü lovak kolosztrumának nagyobb a fehérjetartalma, bár többen a különböző fajták tejének savófehérje-tartalmát azonosnak találták. Ugyan a kancáknál a masztitisz előfordulása nem olyan gyakori, mint a teheneknél, a fertőzött tőgyből származó tej összetétele azonban itt is eltérő lehet az egészségeshez viszonyítva. Tőgygyulladás hatására nő a kóros tej fehérjetartalma (KINGSBURY és GAUNT, 1976; DOREAU et al., 1990; ASILBEKOV, 1980; SOKHTAEV, 1970).

70 különböző korú és fajtájú kanca tejfehérjéjének polimorfizmusát tanulmányozva keményítő gélelektroforézissel, megállapították, hogy a kazein is és a savófehérje is négy különböző frakcióra különíthető el, és a kazein esetében polimorfizmust csak a leggyorsabban mozgó frakcióban tudtak kimutatni. Összehasonlítva a kanca- és a tehéntej fehérjéinek elektroforetikus mozgékonyságát, különbséget tudtak a két faj között megállapítani. A szarvasmarha, a juh, a kecske és a ló kisméretű kazein-micelláit vizsgálva megállapították, hogy a lótej kazein-frakcióinak molekulatömege eltér a másik három vizsgált fajétól (SCHRYVER et al., 1986; CHIOFALO et al., 1983; CONTI et al., 1984; DYUSEMBIN és DIDUK, 1966; MINIERI és INTRIERI, 1970; DYUSEMBIN, 1972).

713 kanca savófehérjéit elemezve keményítő gélelektroforézissel megállapították, hogy a zóna elektroforézissel kapott 1 . frakció 5 genetikai variánst tartalmazott, melyeket A-E-nek neveztek el. A 2. frakció tekinthető a fő savófehérjének, és ezt sikerült $\beta$-laktoglobulinként azonosítani. A harmadik frakció a ló szérumalbumin, a negyedik pedig az a-laktalbumin és egy vaskötő fehérje (talán a transzferrin) keveréke, az ötödik zóna pedig egy vaskötő fehérjét tartalmaz, ami nagy valószínüséggel a laktoferrin. A 6. katódos zóna a ló lizozimot tartalmazta. A szétválasztáson és az azonosításon túl meghatározták még a különböző zónákhoz tartozó fehérjék aminosav-összetételét, és azt hasonlították más állatfajokéhoz. 353 kanca teje savófehérjéinek heterogenitását vizsgálva az a-laktalbumin esetében hét genetikai variánst mutattak ki. Annak ellenére, hogy a $\beta$-laktoglobulin heterogenitására vonatkozó vizsgálatok eredménytelenek maradtak, levonták azt az általános következtetést, hogy a tejfehérjék polimorfizmusa minden állatfajnál általános (lehet), és széleskörü vizsgálatokkal a polimorfizmusok előfordulását bizonyára ki lehet mutatni (EGITO et al., 2002; CONTI et al., 1984; CRAWFORD et al., 1977; VÖRÖS et al., 1999; KINGSBURY és GAUNT, 1976; MINIERI és INTRIERI, 1970; MARKIEWICZ-KESZYCKA et al., 2013).

A ló immunglobulin osztályok és alosztályok szétválasztását, tulajdonságait és frakcióit tanulmányozva megállapították, hogy azok két csoportba oszthatók. Ezek közül az IgGa, IgGb, IgGc és $\operatorname{IgG}(\mathrm{T})$ az IgG alosztályainak tekinthető, míg a többiek (IgM, IgA és az aggregálódó immunglobulinok) önálló osztályokat képeznek. Vizsgálva a kolosztrum és a tej összetételét a laktáció folyamán megállapítják, hogy a kolosztrumban az IgG van jelen a legnagyobb mennyiségben. Az idő múlásával aránya fokozatosan csökken, és már az ellés utáni 5-7. naptól az IgA lesz jelen nagyobb koncentrációban az átmeneti tejben, ill. a tejben. A többi immunglobulin csak az ellés után közvetlenül van jelen nagyobb koncentrációban a tejben, ezt követően mennyiségük rohamosan csökken, és 10-15 nappal az ellés után már eléri a kimutathatóság határát (MARKIEWICZ-KESZYCKA et al., 2013; CONTI et al., 1984; REJNEK et al., 1973; KLEMEN et al., 2011; CIESLA et al., 2009).

29 kanca (16 magyar hidegvérü, 4 haflingi, 6 breton, 3 bouloni) kolosztrumának és tejének fehérjefrakcióit, valamint a fehérjefrakciók változását a laktáció 45. napjáig meghatározva a vizsgált fajták között kolosztrumuk, átmeneti tejük és tejük fehérjetartalmában és fehérje- 
frakcióiban szignifikáns különbséget nem tudtunk kimutatni. Nem találtunk különbséget a fehérjefrakciók megoszlását vizsgálva, és nem volt különbség a kolosztrum és a kolosztrumfehérje aminosav-összetételében és biológiai értékében sem (CSAPÓ-KISS et al., 1995; VÖRÖS et al., 1999).

Közvetlenül az ellés után fejt kolosztrum összesfehérje-tartalma 13,2-22,0\% között változott, átlagosan 16,41\% volt. Ez az érték a 2-5. nap között 4,13\%-ra, a 8-45. nap között pedig 2,31\%-ra csökkent. Mivel a valódifehérje-tartalmat úgy kaptuk meg, hogy az összes fehérjéból levontuk az NPN-t, annak változása gyakorlatilag egybeesik az összes fehérje változásával. Hasonlóan mélyreható változások történnek a savófehérje és a valódi savófehérje-tartalomban közvetlenül az ellés után. E két komponens az ellés után mért 13,5-13,1\%-ról 48-72 óra alatt 2,1-1,8\%-ra, egy-másfél hét alatt pedig 0,9-1,1\%-ra csökken (CSAPÓ-KISS et al., 1995).

Lényegesen kisebb változásokat figyeltünk meg a kazein- és az NPN-tartalom esetében. A kolosztrum kazeintartalma közvetlenül az ellés után 2,95\%, mely 48 óra alatt 2,02\%-ra, egy-másfél hét alatt pedig 1,20\%-ra csökken. A kolosztrum NPN-tartalma mintegy 20\%-kal nagyobb, mint az átmeneti tejé, és mintegy 40\%-kal nagyobb, mint a normális tejé. A fehérjefrakciók megoszlását vizsgálva az összes fehérje \%-ában megállapítható, hogy a valódi fehérje aránya másfél hónap alatt 97-98\%-ról 91\%-ra, a savófehérje és a valódi savófehérje aránya pedig 80-82\%-ról 39-48\%-ra csökken. A vizsgált tartományban a kazein aránya $18 \%$ ról 52\%-ra, az NPN aránya pedig 2,0\%-ról 8,6\%-ra nő (CSAPÓ et al., 1993).

Megállapítottuk tehát, hogy a kolosztrum összesfehérje- és savófehérje-tartalma rohamosan csökken, kazein- és NPN-tartalma pedig nő az ellés utáni másfél hónap alatt. Az előzőekben leírt változások döntő mennyisége az ellés után 48 óra alatt zajlik le, majd ezt követően egy folyamatos lassú változás tapasztalható a laktáció 5. napjáig. A laktáció 5. napja után fejt tej összetétele gyakorlatilag megegyezik a laktáció 45. napján fejt tejével. Az irodalmi adatokhoz viszonyítva általunk kapott kisebb szélsőértékek valószínúleg nem a vizsgált fajták hasonlóságával, hanem inkább a teljesen azonos mintavételi módszer alkalmazásával magyarázhatók. Mi csak azt a mintát tekintettük elsőfejésű kolosztrumnak, amit közvetlenül az ellés után vettünk, mielőtt a csikó szophatott volna. Ha ugyanis a csikó a kolosztrum egy részét kiszopja, a megindult tejelválasztás miatt a kolosztrum erőteljesen felhígul, és összetétele már pár óra alatt egészen más lehet, mint a szopást megelőzően (CSAPÓ et al., 1993; CSAPÓKISS et al., 1994; 1995).

\section{A kolosztrum És A TEJ}

VALAMINT A KOLOSZTRUM- ÉS A TEJFEHÉRJE AMINOSAV-ÖSSZETÉTELE ÉS BIOLÓGIAI ÉRTÉKE

- Amino ACID Composition AND Biological VAlue of Colostrum AND MilK as Well as ColostrumAND Milk Protein

A kancatej és a kancatej-fehérje aminosav-öszszetételéról igen kevés megbízható adat áll rendelkezésre. Megállapítható, hogy a kancatej aminosav-összetétele lényegesen eltér a többi gazdasági állatfajétól. A különböző szerzők által kapott eredmények ugyan számottevően eltérhetnek egymástól, az azonban biztosnak látszik, hogy a kancatej fehérjéje lényegesen több cisztint és glicint tartalmaz, mint a többi állatfajé. A szerzők által kapott különböző eredmények részben az eltérő analitikai módszernek, részben az eltérő mintavételnek köszönhetők. A kancatej szabad aminosav-összetételét meghatározva megállapították, hogy az százszor gazdagabb szabad szerinben és glutaminsavban, mint szabad metioninban (CSAPÓ et al., 1993; CSAPÓ-KISS et al., 1994; CSAPÓ-KISS et al., 1995).

Saját vizsgálataink szerint a kolosztrum szabadaminosav-tartalma - a treonin, a szerin és a glutaminsav kivételével - mintegy kétszer nagyobb, mint a normális tejé. A szabad aminosavak \%-os összetételét vizsgálva szembetűnő, hogy a kolosztrum mintegy ötször több bázikus aminosavat (hisztidin, lizin, arginin) és mintegy fele-harmada annyi savas aminosavat tartalmaz, mint a normális tej. A szabad aminosavak mennyisége a kolosztrumban 
65,79 mg/10og, ami 19,64\%-a az NPN-nek felel meg (o,335\%); a tejnél ezek az értékek 31,60 mg/10og és 15,88\%. Fentiekből következően a kanca kolosztrumának és tejének NPN-tartalmát mintegy 16-20\%-ban a szabad aminosavak alkotják. Úgy tünik, hogy a tej kéntartalmú aminosavai koncentrációja a legkisebb, hisz a tej cisztintartalma százada, metionintartalma pedig csak ezrede pl. a szabad szerinnek ill. glutaminsavnak (CSAPÓ et al., 1993; CSAPÓKISS et al., 1994; CSAPÓ-KISS et al., 1995).

A kolosztrum és a tej valamint a kolosztrum- és a tejfehérje aminosav-összetételét vizsgálva a laktáció 45. napjáig megállapítottuk, hogy az aminosav-tartalom párhuzamosan változik az összesfehérje-tartalommal az ellés után eltelt idő függvényében, tehát minden aminosav kivétel nélkül csökken az első fejésü kolosztrumhoz viszonyítva a laktáció 45. napjáig. A kolosztrum-fehérjében az esszenciális aminosavak többsége (treonin, valin, cisztin, tirozin, lizin) csökken, a nem esszenciális aminosavak közül pedig a kolosztrum-fehérjében meghatározó mennyiségben előforduló glutaminsav és prolin nő az ellés után eltelt idő függvényében. Ennek megfelelően az esszenciális aminosavak összege az ellés utáni első három napban rohamosan csökken, és csak az 5. nap után éri el a normális tejre jellemző szintet. A nem esszenciális aminosavak változása ezzel ellentétes (BALBIERZ et al., 1975; CSAPÓ et al., 1993; CSAPÓ-KISS et al., 1994; CSAPÓKISS et al., 1995; SARKAR et al., 1953).

$\mathrm{Az}$ ellés után közvetlenül fejt kolosztrum-fehérje biológiai értéke $(132,3)$ csaknem eléri a MORUP és OLESEN módszer maximumát jelentő 140-es értéket, ami elsősorban igen magas treonin- és lizintartalmának köszönhető (MORUP és OLESEN, 1976). Ez az érték 2-5 nap alatt - az esszenciális aminosavak menynyiségének csökkenésével - 119,7-re csökken, majd ez a változás folytatódik a 8-45. napig is, ahol a tejfehérje biológiai értéke 107,9 körül alakul. Ez az igen magas biológiai érték (a tehéntejé ugyanezzel a módszerrel számolva 78-82) a magas savófehérje aránnyal és az esszenciális aminosavak - elsősorban a treonin - nagyobb mennyiségével magyarázható (CSAPÓ et al., 1993; CSAPÓ-KISS et al., 1994; CSAPÓ-KISS, 1995).

\section{A KANCA KOLOSZTRUMÁNAK ÉS TEJÉNEK SZÁRAZANYAG-TARTALMA, VALAMINT ZSÍRTARTALMA ÉS ZSÍRSAVÖSSZETÉTELE -}

Dry Matter Content as Well as

FAT CONTENT AND FATTY ACID

COMPOSITION OF MARE'S

Colostrum AND MilK

A kancatej igen alacsony zsírtartalmú. Ez az alacsony zsírtartalom talán több esetben a rossz mintavételi módszereknek, a nem teljesen kifejt csecsből származó tej eltérő összetételének köszönhető, amit bizonyít az is, hogy az utolsó tejrészlet mindig nagyobb zsírtartalmú, mint az előzőek. Az emlősök között csak a rinocérosz tejének kisebb a zsírtartalma (CSAPÓ et al., 1994; CSAPÓ-KISS et al., 1995; HUNDRIESER et al., 1984; BARELLO et al., 2008).

Többen a kancatej zsírtartalmát 0-7,9\% közöttinek találták, melynek eloszlása Gauss-görbe szerint változott. Ezt a hatalmas változatosságot talán a kancák fiziológiai és takarmányozási különbözőségére lehet viszszavezetni. Mások a kancatej zsírtartalmát 1,2\%-nak, a zsírgolyócskák átmérőjét pedig 3,4 $\mu \mathrm{m}$-nek mérték; és a vizsgálatokból úgy tűnik, hogy a kancatej zsírgolyócskáinak nagysága 2-3 $\mu \mathrm{m}$ között van. A tehéntejjel ellentétben a kancatej nemcsak triglicerideket, hanem jelentős mennyiségű (9\%) szabad zsírsavat és 5-19\% foszfolipideket is tartalmaz. A foszfolipidek szfingomielinből (34\%), foszfatidil-etanolaminból (31\%), foszfatidil-kolinból (19\%) és foszfatidil-szerinből (16\%) állnak, de nem tartalmaznak foszfatidil-inozitolt. A kancatej szabad glicerintartalmát o,0056\%-nak mérték, mely érték kapcsolatba hozható a tejzsír nagy szabadzsírsav tartalmával (HOLMES et al., 1947; JAMSRANJAV, 1982; KHARITONOVA, 1978; BARELLO et al., 2008; CSAPÓ et al., 1997; KLEMEN et al., 2011; BRECKENRIDGE és KUKSIS, 1967).

A legtöbb szerző a rövid szénláncú zsírsavakat általában nem, a C10:0-C14:0 zsírsavakat és a hosszú szénláncú zsírsavakat ritkán közli. A legtöbb irodalmi adat a C16:0-C18:3 (palmitinsav, sztearinsav, olajsav, linolsav, linolénsav) közötti zsírsavakat adja csak meg. A kancatejre 
a közepes szénatomszámú zsírsavak nagyobb mennyisége jellemző, és ez jelentős eltérést mutat a kérődzőktől, melyekre a kis szénatomszámú zsírsavak nagyobb mennyisége, és az embertől, melyre a hosszabb szénatomszámú zsírsavak nagyobb mennyisége a jellemző (CSAPÓ et al., 1995; JAMSRANJAV és RABINOVICH, 1974; HADDAD et al., 2011; BASE és ZADRAZIL, 1982; GORIAEV et al., 1970).

A kancatej tejzsírja - hasonlóan a kérődzőkéhez és ellentétben az egyéb monogasztrikus állatokéval - aránylag sok C16-nál kisebb szénatomszámú zsírsavat tartalmaz (20-35\%). Ez talán magyarázható azzal, hogy a lovaknál a tejzsír szintézise acetátból és 3-hidroxi-butirátból történik, mint a kérődzőkben, és nem glükózból, mint a monogasztrikus állatoknál. A 18 szénatomszámú zsírsavak nagyobbik része a kancánál illó zsírsavakból képződik. Ha más fajokkal hasonlítjuk össze a kancatej zsírjának zsírsavösszetételét, akkor megállapítható, hogy a kanca tejzsírja különösen kevés sztearinsavat és több mint 5\% palmitolajsavat tartalmaz. Egy speciális vonása a kanca tejzsírjának nagy linolsav- és különösen linolénsav-tartalma. Ez azzal magyarázható, hogy a telítetlen zsírsavak nem hidrogéneződnek az emésztőrendszerben, mint a kérődzőknél, és hogy a lovak sok olyan takarmányt fogyasztanak, amelyek gazdagok telítetlen zsírsavakban, ugyanis a takarmány és a tejzsír telítetlen zsírsavtartalma szoros összefüggésben van (CSAPÓ et al., 1994; 1997; JAMSRANJAV és RABINOVICH, 1974; JAMSRANJAV és GRIGORJEVA, 1973; JAMSRANJAV, 1982; HADDAD et al., 2011, GORIAEV et al., 1970).

A kancatej zsírtartalmát közvetlenül az ellés után 0,41-3,32\% közöttinek mérték, mely érték a továbbiakban csökkent a laktáció folyamán. Egyesek szerint a kolosztrum zsírtartalma a laktáció 24-48. órájáig nő, majd ezt követően csökken, mások szerint viszont az ellés után közvetlenül mért 1,0-1,7\%-ról a laktáció 7. napjáig 1,8-2,1\%-ra nő. Megállapítják azt is, hogy a tej zsírtartalma az ellés utáni első napon a legnagyobb, majd a továbbiakban rendszertelenül változik a laktáció 14 . napjáig. A különböző szerzők adatait összevetve megállapítható, hogy a kolosztrum zsírtartalma az ellés utáni első 12-24 óra alatt nő, majd ezt követően egyes szerzők szerint gyorsabban, más szerzők szerint lassabban csökken, ami talán összefüggésben lehet a takarmányozással (CSAPÓ et al., 1993; 1995; NAERT et al., 2013; KLEMEN et al., 2011; DOREAU et al., 1990).

Néhány vizsgálatból úgy tünik, hogy a kolosztrum tejzsírjának zsírsavösszetétele nem különbözik lényegesen a normális tejétől. A zsírtartalom és a zsírsavösszetétel változását tanulmányozva az ellés után megállapítják, hogy a laktáció folyamán nem változik a tejzsír zsírsavösszetétele. Mások ezzel szemben kimutatták, hogy a rövid és közepes szénatomszámú zsírsavak mennyisége csökken, a hosszú szénláncú telítetlen zsírsavak aránya viszont nő a laktáció későbbi szakaszában. Néhány kivételtól eltekintve, akik szerint a tej zsírtartalma tendenciájában nem változik a laktáció folyamán - az összes többi szerző szerint a tej zsírtartalma csökken a laktáció folyamán (CSAPÓ et al., 1994; 1995; KLEMEN et al., 2011; BASE és ZADRAZIL, 1982).

Némi csökkenés figyelhető meg a tej zsírtartalmában a kanca korával, de ez a csökkenés alig éri el a 0,2\%-ot, mások szerint viszont a második laktációban a tej zsírtartalma nagyobb, mint az elsőben. A több tejet adó fajták tejének nagyobb a zsírtartalma, mint a kevesebb tejhozamúaké, mások viszont arra a következtetésre jutottak, hogy még az igen nagy testtömeg-különbséggel rendelkező fajták tejének is azonos a zsírtartalma, bár a variációs koefficiensek az összes vizsgált tejalkotó közül a zsírnál a legnagyobbak (ALAGUZHIN, 1964; BELJAJEV és EMRIN, 1977; CSAPÓ et al., 1993; 1995; DOREAU et al., 1990).

Fentieken túl befolyásolja még a tej zsírtartalmát a takarmány energiatartalma, ugyanis a takarmány növekvő energiatartalmával - az abrak arányának megnövelésével a szálastakarmányhoz képest - csökken a tej zsírtartalma, mások szerint viszont a takarmány energiatartalma nincsen hatással a tej zsírtartalmára. Egyesek szerint a takarmány zsírtartalmának növelése nem, mások szerint viszont jelentősen növeli a tej zsírtartalmát (DAVISON et al., 1987; SHRYVER et al., 1986; CSAPÓ és mtsai., 1993; DOREAU et al., 1990; ASCHRAFT és TYZNIK, 1976; SUTTON et al., 1977; PIETRZAK-FIECKO et al., 2009, 2013).

Vizsgálataink szerint a kolosztrum száraza- 
nyag-tartalma közvetlenül az ellés után 24,2526,28\% között változott. Úgy tünik, hogy a magyar hidegvérű lovak kolosztrumának szárazanyag-tartalma a vizsgált fajták között a legnagyobb, azonban ezeket a különbségeket szignifikancia vizsgálattal nem tudtuk megerősíteni. Az elsőfejésű kolosztrum szárazanyag-tartalmának mérésekor a legkisebb eredmény 14,65\%, a legnagyobb pedig 29,35\% volt. A kolosztrum szárazanyag-tartalma rohamosan csökken az ellés után eltelt idő függvényében, és a második napon mért értékek már alig különböznek a laktáció ötödik napja után fejt normális tejétól. A laktáció 2-5. napján fejt átmeneti tej szárazanyag-tartalmát 11,93-12,87\% közöttinek, az 5-8. nap közötti normális tej szárazanyag-tartalmát pedig 10,37-10,61\% közöttinek mértük. A laktáció egyetlen, általunk vizsgált szakaszában sem tudtunk a genotípusok között kolosztrumuk és tejük szárazanyag-tartalmában szignifikáns különbséget kimutatni (CSAPÓ-KISS et al., 1994; CSAPÓ et al., 1993; 1997; SCHRYVER et al., 1986).

A kolosztrum zsírtartalmát közvetlenül az ellés után mértük legnagyobbnak (2,85$2,93 \%)$, mely az átmeneti tej (2,05-2,17\%) és normális tej (1,04-1,32\%) esetében is lényegesen kisebb értéket mutat. A genotípusok között kolosztrumuk, átmeneti tejük és tejük zsírtartalmában szignifikáns különbséget nem tudtunk kimutatni. A kolosztrum és a tej zsírtartalmának változását vizsgálva az ellés után eltelt idő függvényében, illetve a laktáció folyamán azok megállapítását erősítjük meg, akik közvetlenül az ellés után mérték azt a legnagyobbnak (CSAPÓ et al., 1994, 1995, 1997).

A fentiek alapján tehát megállapítható, hogy az első fejésű kolosztrum zsírtartalma átlagosan 2,8-3,0\% között (szélső értékek: 2,123,35\%), a laktáció 5. napja után fejt normális tejé pedig 1,0-1,4\% között (szélső értékek: 0,52-1,94\%) változik. Nem találtunk összefüggést a tejmennyiség és a tej zsírtartalma között, és véleményünk szerint a kanca kora sincs szignifikáns hatással a tej zsírtartalmára (CSAPÓ et al., 1993, 1995).

A kolosztrum és a tejzsír zsírsavösszetételét elemezve megállapítottuk, hogy a kolosztrum tejzsírja kevesebb kaprilsavat, kaprinsavat, laurinsavat, mirisztinsavat, palmitinsavat és palmitolajsavat tartalmaz, mint a normális tejé. Ennek megfelelően a normális tej tejzsírja kevesebb sztearinsavat, linolsavat és linolénsavat tartalmaz, mint a kolosztrumé. A fajták között szignifikáns különbségeket tejzsírjuk zsírsavösszetételében nem tudtunk kimutatni. A kanca és a tehén tejzsírjának zsírsavösszetételét összehasonlítva megállapítható, hogy a kanca tejzsírja másfélszer több laurinsavat, háromszor több kaprinsavat, ötször több linolsavat, tízszer több kaprilsavat és kétszázszor több linolénsavat tartalmaz, mint a tehéné. Ennek megfelelően a kancatej tejzsírjának mirisztinsav-tartalma fele, palmitinsav-tartalma kétharmada, sztearinsav-tartalma pedig ötöde a tehéntej tejzsírjának. Az a nagy különbség, ami a két faj tejzsírjának zsírsavösszetételében - különösen linolénsav-tartalmában - mutatkozik, lehetővé teszi a kancatejhez hozzákevert tehéntej kimutatását és mennyiségének meghatározását (CSAPÓ et al., 1993, 1995).

\section{A kolosztrum és A TEJ} LAKTÓZTARTALMA - LACTOSE Content of Colostrum AND MilK

A kancatej szénhidrát-tartalmának legnagyobb része laktózból áll. A többi cukor csak igen kis koncentrációban fordul elő a kancatejben. A laktózszintézis fó prekurzora a kolosztrum és a tej esetében is a vérból származó glükóz. Közvetlenül az ellés után fejt kolosztrum tejcukor-tartalmát 2,41-4,49\% között mérték, mely 12 óra alatt 4,8-5,2\%-ra, 24 óra alatt 5,4-5,6\%ra, 72 óra alatt pedig 5,6-5,9\%-ra emelkedett, és csak a laktáció 7-10. napja körül érte el a normális tejre jellemző 6,0-6,3\%-os értéket (SANTOS és SILVESTRE, 2008; DAVIES et al., 1983; KULISA, 1980; LINTON, 1937; NAERT et al., 2013; DITTRICH, 1938; DOREAU et al., 1990).

Több száz kanca érett tejének laktóztartalmát meghatározva megállapították, hogy az a kísérletbe vont egyedek 90\%-ánál 6,0-7,0\% között van, mintegy 5\%-ánál 7,oo-8,78\%, a másik 5\%-ánál pedig 1,65-6,00\% közötti laktózt mértek. Az extrém alacsony laktóztartalom valószínúleg összefüggésben lehet a tőgy gyulladásával, míg az extrém magas értékekre jelenleg nincs magyarázat. A rendkívül előrehaladott 
korú kancák tejösszetételét vizsgálva megállapították, hogy az semmilyen tekintetben sem különbözik a fiatalabb kancák tejösszetételétől (KLEMEN et al., 2011). A tej laktóztartalma a laktáció 10. napjától a laktáció 54. napjáig 6,82\%-ról 7,06\%-ra emelkedik, miközben a tej összes energiatartalmának 46,0-55,6\%-át adja. A 24. és 54. nap között vett tejminták átlagos tejcukor-tartalmát 6,91\%-nak, a laktóz részarányát a tej összes energia mennyiségéből 54,2\%nak mérték. A szerzők egy része szerint a tej laktóztartalma nő a laktáció végén, mások szerint viszont nem változik a laktáció folyamán.

A magasabb energiatartalmú és nagyobb nyersfehérje-tartalmú takarmányt fogyasztó kancák a laktáció 14-84. napjának átlagában mintegy o,1\%-kal magasabb laktóztartalmú tejet adtak. Az egymást követő laktációkban az alacsonyabb és a magasabb energiájú takarmányt fogyasztó kancáknál tejük laktóztartalmában nem tapasztaltak változást, tehát ebból a kísérletból is úgy tűnik, hogy a kanca kora nincs hatással a tej laktóztartalmára (PIETRZAK-FIECKO et al., 2009, 2013; KLEMEN et al., 2011).

A laktóz koncentrációjára rendkívül eltérő értékeket közölnek a szakirodalomban. A kolosztrumra közölt 2,7\% a legalacsonyabb, a tejre közölt 7,7\% pedig a legmagasabb, a legtöbb szerző pedig a kancatej laktóztartalmát 5,97,1\%-nak írja le. Egy esetben masztitisz következtében a gyulladásos tejmirigyből származó tej laktóztartalmát 4,3\%-nak mérték. A legtöbb szerző a tej laktóztartalmát a laktáció elején (a kolosztrum periódust követően) 6,0-6,5\%-nak, a laktáció vége felé pedig, a 150. nap környékén, 6,5-7,0\%-nak mérte. A kancatejben a szabad glükóz 0,0084\%, a szabad galaktóz pedig o,0114\% koncentrációban található a 6-7\% koncentrációjú laktóz mellett. A glikoproteinek közül a N-acetil-neuraminsav koncentrációját 0,0047-0,0061\% közöttinek mérték. Francia szerzők szerint a tej laktóztartalma $6,72 \%$, fruktóz-, maltóz-, cellobióz- és szacharóztartalma kevesebb, mint 0,010\%, galaktóztartalma pedig kevesebb, mint 0,072\% (ANWER et al., 1975; BRZESKI és KULISA, 1979; KULISA, 1986a, 1986b; DAVIES et al., 1983; MORRISSEY, 1973; KLEMEN et al., 2011).

Érdekességként megemlíthető, hogy a szamár tejének laktóztartalmát 4,94-6,86\% kö- zöttinek, a Grant zebráét 3,8\%-nak, a Grevy zebráét pedig 5,8\%-nak mérték. Mivel a két zebrafajnál a mintavételi körülmények nem voltak ideálisak, ezért a közölt adatok csak tájékoztató jellegünek tekinthetők (OFTEDAL és JENNESS, 1988).

\section{A kolosztrum És A TEJ MAKRO- ÉS MIKROELEM- TARTALMA - MACRO- AND Microelement Content of Colostrum AND MILK}

Növekvő testtömeggel a tej hamutartalma a Shetland póninál mért o,38\%-ról a Shire fajtánál kapott 0,54\%-ig nő. Sárlás alatt - többek között - megnő a tej hamutartalma. A kolosztrum lényegesen gazdagabb ásványi anyagokban mint a normális tej, ezért hamutartalma elérheti a 0,53-0,77\%-ot is (SCHRYVER et al., 1986; JENNESS, 1974; LUKAS et al., 1972).

Három arab és két quarter horse kanca kolosztrum- és tejösszetételét vizsgálva a laktáció negyedik hónapjának végéig megállapítják, hogy a kolosztrum hamu-, magnézium-, nátrium- és káliumtartalma az ellés utáni 12. óráig hirtelen, ezt követően folyamatosan csökken. A kolosztrum foszfortartalma az ellés utáni 24-48. óráig folyamatosan nő majd csökken, kalciumtartalma pedig az első 12 óra alatti csökkenést követően a 8. napon éri el normális értékét, és hasonlóan a foszforhoz, a továbbiakban csökken a laktáció folyamán. Mások szerint a kancatej hamutartalma az ellés utáni első 14 nap alatt tendenciájában nem mutat változást (CSAPÓ et al., 1997; SCHRYVER et al., 1986; LONNERDAL et al., 1981).

A kanca teje - a többi gazdasági állatfajéhoz hasonlítva - különösen szegény ásványi anyagokban. A szerzők többsége a kancatej hamutartalmát $0,3-0,5 \%$ közöttinek méri, de mint szélsőséges esetet említhetünk $0,2 \%$-os legkisebb, és 0,7\%-os legnagyobb értéket is. Az alacsony hamutartalom kapcsolatba hozható a kancatej kis fehérjetartalmával, melynek köszönhetően alacsony a kancatej kalcium- és foszfortartalma is. Az ásványi anyagok közül a kalcium $61 \%$-a, a foszfor $31 \%$-a, a magnéziumnak pedig 16\%-a van kolloidális alakban a 
kancatejben. A tej kalciumtartalmát 500-1500 mg/kg közöttinek, foszfortartalmát 200-1200 mg/kg közöttinek, magnéziumtartalmát 40$110 \mathrm{mg} / \mathrm{kg}$ közöttinek, nátriumtartalmát 70$200 \mathrm{mg} / \mathrm{kg}$ közöttinek, káliumtartalmát pedig 300-800 mg/kg közöttinek mérték. A kancatej kloridtartalmára 300-600 mg/kg-os értéket kaptak (CSAPÓ-KISS et al., 1994; SCHRYVER et al., 1986).

A kancatej nyomelem-tartalmáról kevés megbízható adat áll rendelkezésre. Az irodalmi adatok - köszönhetően az analitikai módszerek fejlődésének - megbízhatóak, ennek ellenére némely nyomelem koncentrációjában igen nagy eltéréseket lehet megfigyelni. Ezek az eltérések csak részben magyarázhatók metodikai problémákkal; fő okuk talán az, hogy a vizsgált kancák eltérő mikroelem-összetételű takarmányt fogyasztottak, és ez hatással volt a tej nyomelem-tartalmára.

Mi befolyásolja a kancatej ásványianyag-tartalmát? Holland melegvérü hátasló kancák tejösszetételét elemezve az ellés utáni 24. órától a laktáció 28. napjáig megállapították, hogy a tej hamu-, kalcium- és foszfortartalma a 2-3. napig tartó emelkedést követően csökken a vizsgált szakaszban. A laktáció 7. és 56. napja között csökken a tej kalciumtartalma, és a tej hamutartalma is csökken a laktáció folyamán, és ez a csökkenés érvényes a makroelemek többségére és a mikroelemek egy részére is. Fentieken kívül említést érdemelnek azon megállapítások, mely szerint a takarmány energiatartalma nincs hatással a tej ásványianyag-tartalmára, és hogy tőgygyulladás hatására csökken a tej foszfortartalma, nő viszont a kloridionok mennyisége.

Saját vizsgálataink során a kanca kolosztrumának hamutartalmát a laktáció első 48 órájában vett minták átlagában 0,592\%-nak mértük, ahol a szélső értékek 0,804\% és 0,515\% voltak. Ez az érték a 3-5. nap között 0,52\%-ra (szélső értékek: 0,542\% és 0,497\%), a laktáció 8-45. napja között pedig 0,405\%-ra (szélső értékek: 0,479\% és 0,301\%) csökkent (CSAPÓ-KISS et al., 1994).

A makroelemek változását értékelve a laktáció első másfél hónapja alatt megállapítottuk, hogy a kalcium kivételével az összes makroelem csökken a kolosztrum-periódusban és a laktáció elején. Legszembetűnőbb a csökkenés a magnézium esetében, de jelentős csökkenés tapasztalható a káliumnál és a nátriumnál is. A laktáció elején lényegesen kisebb a csökkenés a foszfor esetében; ez az elem csak a laktáció 5. napja után mutat határozott változást. Az előzőekhez képest egész más változást tapasztaltunk a kalcium mennyiségét tanulmányozva. A kancakolosztrum kalciumtartalma közvetlenül az ellés után a legkisebb (748 mg/kg), a laktáció 5. napja körül éri el maximumát $954 \mathrm{mg} /$ kg-mal, majd a továbbiakban - a többi makroelemhez hasonlóan - csökken a laktáció folyamán (CSAPÓ-KISS et al., 1994).

A kanca kolosztruma és teje mikroelem-tartalmának változását vizsgálva az ellés után eltelt idő függvényében megállapítottuk, hogy a cink és a réz folyamatosan csökken, a vas az 5 . nap körüli maximumot követően csökken, a mangán pedig a laktáció 5. napjáig nő, ezt követően pedig konstans szinten marad (CSAPÓKISS et al., 1994).

A kanca és a tehén tejének makro- és mikroelem-tartalmát összehasonlítva megállapítható, hogy a tehéntej majd kétszer több hamut, káliumot, foszfort, magnéziumot és mangánt; másfélszer több kalciumot, vasat és rezet, és majdnem háromszor több nátriumot és cinket tartalmaz, mint a tehéntej. A felsoroltak közül külön figyelmet érdemel a kancatej kis nátriumtartalma, hisz ezt azok a keringési betegségben és magas vérnyomásban szenvedő betegek is fogyaszthatják, akiknek túl nagy a tehéntej $500 \mathrm{mg} / \mathrm{kg}$ körüli nátriumtartalma (CSAPÓKISS et al., 1994).

\section{A kolosztrum ÉS A TEJ}

VITAMINTARTALMA - VITAMIN

Content of Colostrum and MilK

A kancatej A-vitamin-tartalmát $60 \mu \mathrm{g} / \mathrm{dm}^{3}$, E-vitamin-tartalmát $900 \mu \mathrm{g} / \mathrm{dm}^{3}, \quad 25$-hidroxi-kolekalciferol-tartalmát $\quad 15,5 \mu \mathrm{g} / \mathrm{dm}^{3}$, 1,25-dihidroxi-kolekalciferol-tartalmát kevesebb, mint $5,0 \mu \mathrm{g} / \mathrm{dm}^{3}, \mathrm{~B}_{12}$-vitamin-tartalmát $5,48 \mu \mathrm{g} / \mathrm{dm}^{3}$, folsavtartalmát pedig $15,5 \mu \mathrm{g} /$ dm³ közelinek mérték (CSAPÓ et al., 1994; HOLMES et al., 1946).

Saját vizsgálataink során megállapítottuk, hogy a kolosztrum 2,6-szor több A-vitamint, 
1,7-szer több $\mathrm{D}_{3}$-vitamint, 1,4-1,5-ször több Cés K-vitamint és csak kissé több E-vitamint tartalmaz, mint a laktáció 8-45. napja között fejt kancatej. A kancatej A-, $\mathrm{D}_{3}$-, E- és $\mathrm{K}_{3}$-vitaminból gyakorlatilag ugyanannyit tartalmaz, mint a tehéntej, C-vitamin-tartalma pedig annál némileg még nagyobb is (CSAPÓ et al., 1994).

\section{ÖSSZEFOGLALÁS - SUMMARY}

Manapság Nyugat Európában, mint emberi táplálék, jelentősen megnőtt az érdeklődés a kancatej iránt. Sokan úgy gondolják, hogy a kancatej különféle anyagcsere betegségek esetében gyógyhatással rendelkezik, az ára is jelentősen megnőtt a piacon, ezért szükség volt a kancatejet, mint emberi táplálékot értékelni. Mivel kevés adat állt rendelkezésre az összetételről, a szerzők meghatározták a kancatej összetételét. A kísérlet célja volt az is, hogy elemezzék a változásokat az elléstől a laktáció 45. napjáig. Írásukban összegzik kísérleteik eredményeit, és azokat hasonlítva az irodalmi adatokhoz, áttekintést adnak a kanca kolosztrumának és tejének összetételéről.

Megállapították, hogy közvetlenül az ellés után a kolosztrum összesfehérje-, savófehérje-, kazein- és NPN tartalma 16,41, 13,46, 2,95 és 0,052\%, mely a laktáció 2 . és 5 . napja között $4,13,2,11,2,02$ és o,043\%-ra, a 8. és 45. nap között pedig 2,31, 1,11, 1,20 és 0,031\%-ra csökken. A valódi fehérje és a savófehérje aránya ebben a periódusban csökken, míg a kazein és az NPN aránya nő. A kolosztrum és a tej aminosav tartalma csökken a laktáció 45. napjáig, míg a tejfehérje legtöbb esszenciális aminosava (treonin, valin, cisztin, tirozin és lizin) csökken, a glutaminsav- és a prolin-tartalom pedig nő az ellés után. A tejfehérje biológiai értéke az ellés után közvetlenül a legmagasabb $(132,3)$, köszönhetően igen magas treonin- és lizintartalmának. Ez az érték a laktáció 5. napjáig 119,7re, a 45. napjáig pedig 107,9-re csökken.

A kolosztrum és a tej szárazanyag- és zsírtartalma közvetlenül az ellés után 24,25 és $26,28 \%$, valamint 2,85 és $2,93 \%$, a 2 . és 5 . nap között 12,15 és $12,78 \%$, valamint 2,05 és $2.17 \%$ között, a laktáció 8. és 45. napja között pedig 10,37 és 10,61\%, valamint 1,04 és 1.32\% között változott. A tejzsír kaprinsav-, a kaprilsav-, a laurinsav-, a mirisztinsav- és a palmitinsav-tartalma nőtt, míg a sztearinsav-, az olajsav-, a linolsav- és a linolénsav-tartalma csökkent a laktáció folyamán. A kancatej zsírja több kaprilsavat, kaprinsavat, laurinsavat, linolsavat és linolénsavat, és kevesebb sztearinsavat, mirisztinsavat és palmitinsavat tartalmazott, mint a tehéntejé. A kancatej esszenciális zsírsavtartalma magasabb volt, mint a tehéntejé.

A kolosztrum A-, D-, K- és C-vitamin-tartalma (o,88, 0,0054, 0,043, 23,8 mg/kg) 1,4 és 2,6-szorosa volt a normál tejének (0,34, 0,0032, 0,029, 17,2 mg/kg). Nem volt szignifikáns különbség a kolosztrum és a tej E-vitamin-tartalmában.

A kolosztrum hamutartalma szignifikánsan nagyobb (0,592\%), mint a normál tejé (0,405\%). Az ellés után közvetlenül volt a legalacsonyabb a kolosztrum kalcium-tartalma $(747,7 \mathrm{mg} / \mathrm{kg})$, mely az 5 . napon érte el maximumát $(953,7 \mathrm{mg} / \mathrm{kg})$. A cink- és réztartalom az 5. napon mutatott maximum után csökkent, míg a mangán koncentrációja az 5. napi maximum után változatlan maradt. A kolosztrum és a tej makro- és mikroelem-tartalmára az alábbiakat határozták meg: kálium, 928,6 és 517,2; nátrium, 320,o és 166,6; kalcium, 747,7 és 822,9; foszfor, 741,7 és 498,8; magnézium, 139,7 és 65,87; cink, 2,95 és 1,99; vas, 0,996 és 1,209; réz, 0,606 és 0,249 és mangán, 0,0447 és $0,0544 \mathrm{mg} / \mathrm{kg}$. A kancatej alacsony nátrium-tartalma előnyös lehet a szív-érrendszeri panaszokkal, ill. magas vérnyomással küzdő emberek számára.

\section{KöSZÖNETNYILVÁNÍTÁS -}

\section{ACKNOWLEDGEMENT}

A szerzők köszönetüket fejezik ki a Debreceni Egyetem Mezőgazdaság-, Élelmiszer-tudományi és Környezetgazdálkodási Kar, Élelmiszer-technológiai Intézetnek és a Sapientia Erdélyi Magyar Tudományegyetem Kolozsvár, Csíkszeredai Kar, Élelmiszer-tudományi Tanszéknek az anyagi és erkölcsi támogatásért.

A publikáció elkészítését az EFOP-3.6.3VEKOP-16-2017-00008 számú projekt támogatta. A projekt az Európai Unió támogatásával, az Európai Szociális Alap társfinanszírozásával valósult meg. 


\section{IRODALOMJEGYZÉK - REFERENCES}

Alaguzhin, A. (1964): Milk Productivity of Lokai Mares. Konevodstvo Konnyi Sport. 34 13-14.

Aschraft, A. - Tyznik, W. J. (1976): Effect of Diet on Volume and Composition in Mare's Milk. Journal of Animal Science. 43248.

Asilbekov, B. A. (1980): Comparison of Methods for Diagnosis of Subclinical Mastitis in Machine-Milked Mares. Dairy Science Abstr. 42112.

Balbierz, H. - Nikolajczuk, M. Poliwoda, A. - Ruda, M. (1975): Study of Whey Proteins of Mares' Colostrum and Milk During Nursing. Polskie Archiwum Weterynaryjne. 18 455-465.

Base, J. - Zadrazil, K. (1982): Fatty Acid of Milk Fat in Mare's Milk. XXI. Int. Dairy Congr. 621-622.

Beljajev, A. - Emrin, G. (1977): Milk Productivity of Kushum Mares. Konevodstvo Konnyi Sport. 529.

Breckenridge, W. C. - Kuksis, A. (1967): Molecular Weight Distribution of Milk Fat Triglycerides from Seven Species. Journal of Lipid Research. 8 473-478.

Brzeski, E. - Kulisa, M. (1979): Pozium kwasu N-acetylneuraminowego i tluszczu w mleku klaczy araskich. Rocz. Nauk. Roln. 6 29-35.

Chiofalo, L. - Micari, P. - Sturniolo, G. (1983): Polimorfismo delle proteine del latte in populazioni cavalline allevate in Sicilia. Zootech. Nutr. Anim. 9 311-318.

Cebo, C. - Rebours, E. - Henry, C. Makhzami, S. - Cosette, P. - Martin, P. (2012): Identification of Major Milk Fat Globule Membrane Proteins from Pony Mare Milk Highlights the Molecular Diversity of Lactadherin Across Species. Journal of Dairy Science. 95 (3) 10851098. https://doi.org/10.3168/jds.20114455

Cieśla, A. - Palacz, R. - Janiszewska, J. - Skórka, D. (2009): Total Protein, Selected Protein Fractions and Chemical Elements in the Colostrum and Milk of Mares. Archiv Tierzucht. 52 (1) 1-6. https://doi.org/10.5194/aab-52-1-2009
Conti, A. - Godovac-Zimmerman, J. - Liberatori, J. - Braunitzer, G. (1984): The Primary Structure of Monomeric Beta-Lactoglobulin from Horse Colostrum. Hoppe-Seyler's Z. Phisiol. Chem. 365 (2) 1393-1401. https:// doi.org/10.1515/bchm2.1984.365.2.1393

Crawford, T. B. - McGuire, T. C. Hallowell, A. L. (1977): Failure of Colostral Immunglobulin Transfer as an Explanation for Most Infections and Deaths of Neonatal Foals. Journal of the American Veterinary Medical Association. 170 (11) 1302-1304.

Csapó, J. - Stefler, J. - Martin, T. G. Makray, S. - Csapó-Kiss, Zs. (1994): Fat Content, Fatty Acid Composition and Vitamin Content of Mare's Milk. Acta Alimentaria. 23 167-176.

Csapó-Kiss, Zs. - Stefler, J. - Martin, T. G. - Makray, S. - Csapó, J. (1994): Protein Content, Amino Acid Composition, Biological Value and Macroand Microelement Content of Mare's Milk. Acta Alimentaria. 23 177-192.

Csapó, J. - Stefler, J. - Martin, T. G. Makray, S. - Csapó-Kiss, Zs. (1995): Composition of Mare's Colostrum and Milk. Fat Content and Fatty Acid Composition. International Dairy Journal. 5 (4) 393402. https://doi.org/10.1016/09586946(94)0ooo8-D

Csapó-Kiss, Zs. - Stefler, J. - Martin, T. G. - Makray, S. - Csapó, J. (1995): Composition of Mare's Colostrum and Milk. Protein Content, Amino Acid Composition and Biological Value. International Dairy Journal. 5 (4) 403415. https://doi.org/10.1016/09586946(94)00014-G

Csapó, J. - Stefler, J. - Herczog, E. - Csapó, Jné (1993): A kanca tejének összetétele. I. A kolosztrum és a tej zsírtartalma és zsírsavösszetétele. Állattenyésztés és Takarmányozás. 42 131-146. 
Csapó, J. - Stefler, J. - Makray, S. - Csapó, Jné. (1993): A kanca tejének összetétele. II. A kolosztrum és a tej fehérjetartalma, fehérjefrakciói, aminosav összetétele és biológiai értéke. Álattenyésztés és Takarmányozás. 42 407-418.

Csapó, Jné - Stefler, J. - Makray, S. - Csapó, J. (1994): A kanca tejének összetétele. III. A kolosztrum és a tej makroés mikroelem-tartalma. Állattenyésztés és Takarmányozás. 43 321-330.

Csapó-Kiss, Zs. - Makray, S. - Stefler, J. - Martin, T. G. - Csapó, J. (1994): Macro- and Microelement and Vitamin Contents of Mare's Colostrum and Milk. 45th Annu. Meet. of European Association for Animal Production. Edinburgh, Scotland, September 5-8. 367.

Csapó, J. - Csapó-Kiss, Zs. - Stefler, J. (1997): Determination of Small Quantities of Cow's Milk Blended with Mare's Milk Based on Fatty Acid Composition. 48th Annual Meeting of the European Association for Animal Production. Vienna, Austria, August 25-28. 393.

Csapó, J. - Csapó-Kiss, Zs. - Stefler, J. (1997): Determination of Small Quantities of Cow's Milk Blended with Mare's Milk Besed on the Fatty Acid Composition of the Milk Fat. Authenticity and Adulteration of Food - the Analytical Approach. Euro Food Chem IX. Interlaken, Switzerland, September 24-26. 363-368.

Davies, D. T. - Holt, C. - Christie, W. W. (1983): The Composition of Milk. Biochemistry of Lactation. Elsevier Amsterdam. 71-117.

Davison, K. E. - Potter, G. D. - Greene, L. W. - Evans, J. W. - McMullan, W. C. (1987): Lactation and Reproductive Performance of Mares Fed Added Dietary Fat During Late Gestation and Early Lactation. Proc. 1oth Eq. Nutr. Physiol. Symp., Colorado State Univ., 87-92.

Dittrich, H. (1938): A Study of the Composition of Mare's Milk. Milchwirtschaftliche Forschungen. 19 406-412.
Doreau, M. - Boulot, S. (1989): Methods of Measurement of Milk Yield and Composition in Nursing Mares: A Review. Le Lait. 69 (3) 159-161. https://doi. org/10.1051/lait:1989313

Doreau, M. - Boulot, S. - Barlet, J. P. - Patureau-Mirand, P. (1990): Yield and Composition Of Milk from Lactating Mares: Effect of Lactation Stage and Individual Differences. Journal of Dairy Research. 57 (4) 449-454. https://doi. org/10.1017/So022029900029496

Duisembaev, K. I. (1973): Mare Milk Proteins. Trudy Alama-Atinskogo Zooveterinarnogo Instituta. 23 76-80.

Dyusembin, K. (1972): Uneven Distribution of Major Milk Components in Consecutive Portions of a Milking in Farm Animals. Trudy Inst. Fiziol. Alma-Ata. 17 42-45.

Dyusembin, K. - Diduk, J. (1966): Effect of Age and Number of Lactations on Composition of Mare Milk. Trudy Inst. Fiziol. Akad. Nauk. Kazekh. Alma-Ata. 10 158-161.

Egito, A. S. - Miclo, L. - López, C. - Adam, A. - Girardet, J. M. - Gaillard, J. L. (2002): Separation and Characterization of Mares' Milk as1-, $\beta$-, $\kappa$-Caseins, $\gamma$-CaseinLike, and Proteose Peptone Component 5-Like Peptides. Journal of Dairy Science. American Dairy Science Association. 85 (4) 697-706. https://doi.org/10.3168/jds. So022-0302(02)74126-X

Gibbs, P. D. - Potter, G. D. - Blake, R. W. - McMullan, W. C. (1982): Milk Production of Quarter Horse Mares During 150 Days of Lactation. Journal of Animal Science. 54 (3) 496-499. https:// doi.org/10.2527/jas1982.543496x

Goriaev, M. I. - Shafieva, L. K. Denisova, L. G. (1970): Fatty Acid Composition of Fat in Mares Milk and Coumiss. Molotsnaya Promyshlennost. 31 22-24.

Haddad, I. - Massimo, M. - Rosanna, S. - Frega, N. G. (2011): Fatty Acid Composition and Regiodistribution in Mare's Milk Triacylglycerols at Different Lactation Stages. Dairy Science \& Technology. 91 (4) 397-412. https://doi. org/10.1007/s13594-011-0020-y 
Holmes, A. D. - McKey, B. V. - Wertz, A. W. - Lindquist, H. G. - Parkinson, L. R. (1946): The Vitamin Content of Mare's Milk. Journal of Dairy Science. 29 (3) 163-171. https://doi.org/10.3168/jds. Soo22-0302(46)92462-9

Holmes, A. D. - Spelman, A. F. Smith, C. T. - Kozmesk, J. W. (1947): Composition of Mare's Milk as Compared with Other Species. Journal of Dairy Science. 30 385-395. https://doi. org/10.3168/jds.Soo22-0302(47)92363-1

Hundrieser, K. E. - Clark, R. M. Jensen, R. G. - Ferris, A. M. (1984): A Comparison of Methods for Determination of Total Lipids in Human Milk. Nutrition Research. 4 (1) 21-26. https://doi. org/10.1016/So271-5317(84)80129-3

Jamsranjav, N. - Grigorjeva, V. N. (1973): Distribution of Fatty Acids in Glycerides of Mare's Milk Lipids. Izv. Vyssh. Uchebn. Zaved. Pishch. Tekhnol. 5 34-36.

Jamsranjav, N. - Rabinovich, P. M. (1974): Fatty Acid Composition of Mare Milk Fat. Molochnaya Promyshlennost. 1 45-46.

Jamsranjav, N. (1982): Cow and Mare Milk Fatty Acid Composition. XXI. Int. Dairy Congr. Moskow. 195-196.

Jenness, R. (1974): The Composition of Milk. In: Larson B. L. - Smith V. R.: Lactation of Mare. Acad Press, London, 3-107. https://doi.org/10.1016/B978-012-436703-6.50007-7

Kharitonova, I. (1978): Fatty Acids and Phospholipids in Mare Milk. Konevodstvo Konnyi Sport. 1224.

Kingsbury, E. T. - Gaunt, S. N. (1976): Heterogeneity in Whey Protein of Mare's Milk. Journal of Dairy Science. 60 (2) 274-277. https://doi.org/10.3168/jds. So022-0302(77)83864-2

Klemen, P. - Vesna, G. - Krešimir, K. - Angela, C. (2011): Mare's Milk: Composition and Protein Fraction in Comparison with Different Milk Species. Mljekarstvo. 61 (2) 107-113.

Kulisa, M. (1980): Lactose, Free Glucose and Galactose Levels in the Milk of Arab Mares. Rocz. Nauk. Zootech. 7 31-36.
Kulisa, M. (1986a): Some Components of Mare Milk. Proc. 37th Annu. Meet. EAAP, Budapest.

Kulisa, M. (1986b): Selected Amino Acids, Fatty Acids and N-Acetylneuramic Acid in Mare Milk. Proc. 37th Annu. Meet. EAAP, Budapest.

Linton, R. G. (1937): The Composition of Mare's Milk. Journal of Dairy Science. 8 143-172.

Lonnerdal, B. - Keen, C. L. - Hurley, L. S. (1981): Iron, Copper, Zinc and Manganese in Milk. Annual Review of Nutrition. 1 149-174. https://doi.org/10.1146/annurev. nu.01.070181.001053

Lukas, V. K. - Albert, W. W. - Owens, F. N. - Peters, A. (1972): Lactation of Shetland Mares. Journal of Animal Science. 34350.

Malacarne, M. - Martuzzi, F. - Summer, A. - Mariani, P. (2002): Protein and Fat Composition of Mare's Milk: Some Nutritional Remarks with Reference to Human and Cow's Milk. International Dairy Journal. 12 (11) 869-877. https:// doi.org/10.1016/So958-6946(02)00120-6

Markiewicz-Keszycka, M. - Wójtowski, J. - Kuczynska, B. - Puppel, K. Czyzak-Runowska, G. - Bagnicka, E. - Strzakowska, N. - Józwik, A. - Krzyzewski, J. (2013): Chemical Composition and Whey Protein Fraction of Late Lactation Mares' Milk. International Dairy Journal. 31 (2) 62-64. https://doi. org/10.1016/j.idairyj.2013.02.006

Minieri, L. - Intrieri, F. (1970): Ricerche ellettroforetiche sulle frazioni proteiche del colostro e del latte di cavalle di razza avelignese, in ropporto alla distanza dal parto. Acta Med. Vet. Napoli. 16 73-88.

Morrissey, P. A. (1973): The N-Acetylneuraminic Acid Content of the Milk of Various Species. Journal of Dairy Research. 40 (3) 421-425. https://doi.org/10.1017/ So022029900014795

Morup, K. - Olesen, E. S. (1976): New Method for Prediction of Protein Value from Essential Amino Acid Pattern. Nutrition Reports International. 13 355365 . 
Naert, L. - Vandevyvere, B. - Verhoeven, G. - Duchateau, L. - De Smet, S. - Coopman, F. (2013): Assessing Heterogeneity of the Composition of Mare's Milk in Flanders. Vlaams Diergeneeskundig Tïdschrift. 82 (1) 2330.

Oftedal, O. T. - Jenness, R. (1988): Interspecies Variation in Milk Composition Among Horses, Zebras and Asses (Perissdactyla: Equidae). Journal of Dairy Research. 55 (1) 57-66. https://doi. org/10.1017/Soo22029900025851

Pagan, J. D. - Hintz, J. F. (1986): Composition of Milk from Pony Mares Fed Various Levels of Digestible Energy. Cornell Veterinarian. 76 (2) 139-148.

Pietrzak-Fiećko, R. - Tomczyński, R. - Świstowska, A. - Borejszo, Z. - Kokoszko, E. - Smoczyńska, K. (2009): Effect of Mare's Breed on the Fatty Acid Composition of Milk Fat. Czech Journal of Animal Science. 54 (9) 403407. https://doi.org/10.17221/1683-CJAS

Pietrzak-Fiećko, R. - Tomczyński, R. Stefan, S. - Smoczyńska, K. (2013): Effect of Lactation Period on the Fatty Acid Composition in Mares' Milk from Different Breeds. Archiv Tierzucht. 56 (33) 335-343.

Rejnek, J. - Prokesova, L. - Stezl, K. (1973): The Presence of Igg and Igm in Fulterm Horse Umbilical Cord Sera. Immunochemistry. 10 (6) 397399. https://doi.org/10.1016/o0192791(73)90146-8

Santos, A. S. - Silvestre, A. M. (2008): A Study of Lusitano Mare Lactation Curve with Wood's Model. Journal of Dairy Science. 91 (2) 760-766. https://doi. org/10.3168/jds.2007-0057
Sarkar, B. C. R. - Rykala, A. J. - Duncan, C. W. (1953): The Essential Amino Acid Content of the Proteins Isolated from Milk of the Cow, Ewe, Sow, and Mare. Journal of Dairy Science. 36 (8) 859864. https://doi.org/10.3168/jds.Soo220302(53)91573-2

Schryver, H. F. - Oftedal, O. T. Williams, J. - Soderholm, I. V. Hintz, H. F. (1986): Lactation in the Horse: The Mineral Composition of Mare Milk. The Journal of Nutrition. 116 (11) 2142-2147. https://doi.org/10.1093/ jn/116.11.2142

Sokhtaev, M. K. (1970): Milk Composition of Karabair Mares. Dokl. Mosk. Selkohoz. Akad. Zootekh. 157 211-215.

Sutton, E. I. - Bowland, J. P. - Ratcliff, W. D. (1977): Influence of Level of Energy and Nutrient Intake by Mares on Reproductive Performances and Blood Serum Composition of the Mares and Foals. Canadian Journal of Animal Science. 57 (3) 551-558. https://doi. org/10.4141/cjas77-071

Tyler, S. (1972): The Behaviour and Social Organisation of New-Forest Ponies. Animal Behaviour Monographs. 5 (2) 85196.

Vörös, O. - Csapó, J. - Baranyi, M. Csapó-Kiss, Zs. - Stefler, J. (1999): A tejfehérje vizsgálata poliakrilamid gélelektroforézissel és izoelektromos fókuszálással kancatejből. Acta Agraria Kaposváriensis. 3 (1) 1-10. 